ROCZNIKI PEDAGOGICZNE

Tom 11(47), numer 2 - 2019

DOI: http://dx.doi.org/10.18290/rped.2019.11.2-3

KRYSTYNA CHAŁAS

\title{
OSOBA PUNKTEM WYJŚCIA I DOJŚCIA W EDUKACJI WCZESNOSZKOLNEJ
}

\section{CZŁOWIEK JAKO OSOBA}

Personalistyczne ujęcie nauczyciela i ucznia wyznacza perspektywę celów, treści, sytuacji wychowawczo-dydaktycznych, zasad dydaktycznych, strategii działania, relacji interpersonalnych. W kontekście tematu przedstawianego opracowania centralnym zagadnieniem jest osoba nauczyciela i ucznia. Wyrasta więc zadanie nakreślenia, choćby w skrótowej formie, istoty osoby. Analiza różnych stanowisk zawartych $\mathrm{w}$ coraz bogatszej literaturze wskazuje, że pojęcie osoby ogniskuje takie zagadnienia, jak: indywidualność, osobowość, świadomość, natura rozumna, organizm, duch, wartość niepowtarzalna i nieprzemijająca, autonomia.

Syntetyczną charakterystykę osoby ludzkiej znajdujemy w Encyklopedii Aksjologii Pedagogicznej: „osoba - z racji swej godności - cechuje się doskonałością bytową i jednocześnie ma charakter normatywny $\mathrm{w}$ dziedzinie moralności, prawa, wychowania, polityki, ekonomii i innych obszarów ludzkiej działalności” (Wierzbicki, 2016, s. 694).

Istota osoby zawiera się w jedności cielesno-duchowej. Te dwie strony osoby ludzkiej są ze sobą zintegrowane, wzajemnie się dopełniają. „,Człowiek jest osobą - pisze K. Wojtyła - stanowi on nie tylko jednostkę w obrębie swojego gatunku, ale każda taka jednostka, każde ludzkie indywiduum posiada ten szczególny rys i znamię osobowości” (Wojtyła, 2003, s. 95). Autor stawia pytanie „,w czym ten rys się wyraża?" (Wojtyła, 2003, s. 95). Tym szczególnym wyrazem rysu osoby jest jej pierwiastek duchowy, duchowość człowieka. K. Wojtyła podkreśla, że „osobą może być tylko byt duchowy, bo tylko na kanwie duchowości daje się pojąć świadomość i wolność. One zaś obie warunkują odpowiedzialność. Wszyst-

Prof. dr hab. KRYSTYNA CHA£AS - kierownik Katedry Dydaktyki i Edukacji Szkolnej, Instytut Pedagogiki KUL, Lublin; e-mail: kryschal@kul.pl 
kie zaś owe rysy stanowią przejawy życia i bytu osobowego. Dzięki nim człowiek to nie tylko indywiduum ludzkiego gatunku, ale to przede wszystkim pewna wewnętrzna duchowa treść ściśle niepowtarzalna, właściwa tylko tej jednostce, treść, której nie da się przypisać innemu ,ja”, do niego odnieść, w nim jako własną uświadomić, za nią wreszcie jako za własną ponieść odpowiedzialność" (Wojtyła, 2003, s. 95). M. Nowak zauważa, że „osoba jest nie tylko fenomenem naznaczonym niepowtarzalnością, jednością, substancjalnością, ale także potencjalnością, zdolnością stawania się i rozwoju, wartościowania i realizowania wartości, a nade wszystko transcendencji” (Nowak, 2013, s. 16).

W świetle personalizmu człowiek jest osobą, a tym samym jest wartością niepowtarzalną i nieprzemijającą" (Wojtyła, 2003, s. 95).

Osoba posiada przymioty. Są nimi: godność, rozumność-mądrość, wolność, odpowiedzialność, zdolność do miłości, twórczości, transcendencji.

\section{PRZYMIOTY OSOBY LUDZKIEJ I ICH TREŚCIOWY WYMIAR W EDUKACJI WCZESNOSZKOLNEJ}

Stawiając osobę w punkcie wyjścia i dojścia w edukacji wczesnoszkolnej, stawiamy jednocześnie jej przymioty. Powstaje pytanie o treściowy ich wymiar w perspektywie punktu wyjścia i dojścia w edukacji wczesnoszkolnej.

Godność osoby - najogólniej określana jest jako niepowtarzalna wartość osoby. Ogniskuje takie pojęcia, jak: „człowieczeństwo, dostojeństwo, dobra sława, dobre imię, cześć, honor, duma, powaga, uznanie moralne, poważanie, szacunek dla siebie i innych, szlachetność, miłość bliźniego, poczucie braterstwa, zaszczyt, humanizm, podmiotowość, autonomia, prestiż, zacność, przyzwoitość, czcigodność, dzielność moralna, ambicja, przeżywanie własnej wartości, godność sumienia, postawy godne, przywracanie komuś czci”(Skorowski, 2014, s. 331). Z pedagogicznego punktu widzenia na uwagę zasługuje określenie godności w Encyklopedii Katolickiej „godność (łac. dignitas), szczególna wartość człowieka jako osoby pozostającej w relacjach interpersonalnych (ostatecznie do Osoby Boga), uzasadniająca i usensowniająca życie osobowe, a także pozytywnie wartościująca relacje do własnej osoby i grupy (np. zawodowej, klasowej, narodowej), z którymi jednostka się identyfikuje. Konstytuującym komponentem tego ustosunkowania się jest samoocena polegająca na przeżywaniu swojej wartości, pozytywnego obrazu samego siebie, która motywuje do moralnie wartościowych zachowań, uodparnia na wszelkie formy manipulacji i zniewalania oraz wpływa na radzenie sobie w sytuacjach trudnych; godność zakłada poczucie wewnętrznej 
wolności, autodeterminacji (podmiotowości) i odpowiedzialności” (Chlewiński, Zaleski, 1989, s. 1231).

Analiza powyższego określenia godności wskazuje na zawarte w nim cele wychowania. Wśród nich występują: poszanowanie własnej wartości, budowanie pozytywnego obrazu siebie, budowanie przestrzeni własnej wolności, podmiotowości, kształtowanie postawy odpowiedzialności, rozwijanie umiejętności rozwiązywania problemów, budowanie pozytywnych relacji interpersonalnych.

Odnosząc godność do osoby nauczyciela i ucznia w aspekcie punktu wyjścia należy podkreślić, że po stronie zarówno nauczyciela, jak i ucznia jest zdobycie wiedzy o godności osobowej i osobowościowej, zrozumienie, że godność osobowa i osobowościowa jest wielką wartością. Godność osobowa jest dana, nieutracalna, nieprzemijająca. Godność zaś osobowościowa jest zadana, utracalna. Można ją utracić poprzez działania niemoralne. Zdobywanie zasobu wiedzy o tej wartości, zrozumienie jej ważności powinno stanowić punkt wyjścia do jej interioryzacji i internalizacji, do budzenia wrażliwości na tę wartość, budzenia gotowości do jej urzeczywistniania i wreszcie jej urzeczywistnianie tu, teraz i w przyszłości. Wyrasta więc po stronie nauczyciela i ucznia zadanie: podjęcie edukacji aksjologicznej w zakresie fenomenu godności. Należy podkreślić, iż godność osobowa nauczyciela jest nierozerwalnie złączona $\mathrm{z}$ godnością zawodową, w którą wpisana jest jego misja i wierność swojemu powołaniu. Co stanowi zatem punkt dojścia? Po stronie zarówno nauczyciela i ucznia edukacji wczesnoszkolnej jest posiadanie wysokiego poziomu wiedzy (na miarę pełnienia swej roli) o tej wartości; poszanowanie własnej godności i godności drugiego człowieka, w tym poszanowanie przez nauczyciela godności ucznia i poszanowanie przez ucznia godności nauczyciela; afirmacja godności, a jeśli zachodzi potrzeba jej obrona w stanie zagrożenia, posiadanie kompetencji godnościowych (na miarę pełnienia swej roli). Drugim przymiotem osoby jest rozumność-mądrość. Człowiek-osoba, a tym samym nauczyciel i uczeń są istotami rozumnymi. Posiadają zdolności poznawcze: pamięć, wyobraźnię, uwagę, myślenie oraz inteligencję. Te dwa podmioty edukacji powinna cechować mądrość. Najogólniej jest ona określana jako wiedza połączona $\mathrm{z}$ inteligencją, $\mathrm{z}$ rozeznaniem i zachowaniem - na miarę wartości osoby - jej godności osobowej (Słownik wspótczesnego języka polskiego, 1998, s. 500). Postrzegana jest jako cnota intelektualna, sprawność i cnota moralna (Nowak, 2016, s. 572).

Po stronie nauczyciela punktem wyjścia w edukacji wczesnoszkolnej jest zgłębianie swojej mądrości; wyposażenie uczniów w wiedzę o tej wartości, a więc edukacja aksjologiczna w zakresie wielkiej wartości, jaką jest mądrość. 
Wiąże się to z rozwijaniem swoich zdolności intelektualnych, posiadanej wiedzy, zdolności krytycznej oceny, otwartości na nowe doświadczenia, rozwijaniem zdolności uczenia się, jak również przejawianiem troski o uczniów, gotowości i zdolności służenia im pomocą, radą, rozumieniem ich potrzeb, problemów oraz reflektowanie intencji podejmowania działań pedagogicznych i ich celów (Steuden, 2011, s. 74). Ważnym zadaniem nauczyciela jest stworzenie sytuacji pozwalających dokonywać wartościującego oceniania zdarzeń, procesów, działań, zjawisk w kategoriach dobra i zła oraz stwarzanie uczniom szansy podejmowania wolnych decyzji i wyborów według kryterium rozwoju dojrzałej osobowości, bycia wzorem osobowym godnym naśladowania. Mądrość tych dwóch podmiotów konstytuowana jest przez rozeznanie w dobru i wybór dobra. Po stronie zaś ucznia wyrasta zadanie zdobywania wiedzy o zdolnościach poznawczych oraz praca nad ich rozwijaniem; reflektowanie swojej mądrości poprzez analizę swojego postępowania według kategorii dobra i zła. Punktem zaś dojścia zarówno po stronie nauczyciela i ucznia będzie przejawianie swojej mądrości, dawanie świadectwa mądrych decyzji, wyborów, działań.

Mądrość człowieka integralnie jest związana z jego wolnością - kolejnym przymiotem osoby. Określana jest jako „zdolność i możliwość wyboru wartości i opowiedzenia się za nimi. Wyraża się w życiu zgodnym z własnym sumieniem. Jest związana z prawdą i dobrem: wyrasta z prawdy i ukierunkowuje się ku dobru. Nie jest tożsama z brakiem jakichkolwiek norm" (Nawosad, Wyrostkiewicz, 2014, s. 586). Wolność urzeczywistniana jest w życiu wewnętrznym i wspólnotowym. Związana jest z panowaniem nad sobą, pracą nad sobą, samowychowaniem, kierowaniem swoim postępowaniem zgodnie z przyjętymi normami moralnymi, zasadami współżycia społecznego i przyjętymi obowiązkami, stawianiem sobie wysokich wymagań, autoformacją (Matulka, 1997, s. 249). Należy przy tym podkreślić, że zarówno uczeń jak i nauczyciel muszą zrozumieć, że wolność wymaga wysiłku ascetycznego. Wysiłek ten jest podstawowym czynnikiem dynamizowania dojrzewania do wolności godnej osoby ludzkiej:

- nie ma wolności bez samowychowania, autoformacji, stawiania sobie wysokich wymagań i rzetelnego podejmowania działań, by sprostać tym wymaganiom;

- prawda jest fundamentem wolności;

- najdoskonalszym spełnieniem jest miłość;

- $\quad$ wolność jest darem i zadaniem, wymaga odpowiedzialności.

Rozpatrując wolność jako punkt wyjścia i dojścia w procesie edukacji szkolnej należy uwzględnić dwie jej kategorie: wolności od (zła, nacisków zewnętrznych, 
słabości człowieka - od antywartości) i wolność do (wyboru dobra, urzeczywistniania właściwej hierarchii wartości, twórczości, integralnego rozwoju, pełni człowieczeństwa).

W punkcie wyjścia po stronie nauczyciela jest zdobywanie wiedzy o fenomenie wolności, przekazywanie jej uczniom, przejawianie postawy świadczącej o urzeczywistnianiu tej wartości, dawanie świadectwa bycia wolnym człowiekiem. Po stronie zaś ucznia będzie zdobywanie wiedzy o wolności, zrozumienie jej istoty i funkcji w życiu wewnętrznym i społecznym, reflektowanie swojej wolności. Punktem dojścia urzeczywistniania wartości wolności w procesie edukacji wczesnoszkolnej zarówno po stronie nauczyciela i ucznia jest głębokie poczucie (na miare pełnionej roli i sytuacji rozwojowej), wolności oraz bycie wzorem osobowym człowieka wolnego; do wyboru dobra i wolnego od zła - wszystkiego, co zniewala i redukuje człowieczeństwo. $Z$ wolnością związana jest odpowiedzialność - kolejny przymiot osoby ludzkiej. Jest integralnie związana z podmiotowym rozwojem intelektualnym, psychicznym, społecznym, moralnymi działaniami człowieka, orientacją aksjologiczną, tożsamością człowieka. Określana jest jako ,cecha moralnego postępowania osoby w sensie, który wypływa z dobrowolności postępowania; w którym skutki działania (również przedstawiająca je intencja) są podstawą oceny człowieka jako sprawcy tych skutków z perspektywy określonego systemu reguł moralnych" (Chłodna-Błach, 2016, s. 670). Odpowiedzialność jest związana $\mathrm{z}$ prawdą, wyraża się w służbie prawdzie i ponoszeniu konsekwencji własnych działań, bardzo często wymagających ryzyka, poszukiwania i wybierania prawdy. Według K. Wojtyły źródło odpowiedzialności tkwi w powinności moralnej i tym samym odpowiedzialność związana jest $\mathrm{z}$ sumieniem. Człowiek ponosi odpowiedzialność za te czyny, które powinien spełnić i co do których nie ma moralnych wątpliwości (Wojtyła, 2000, s. 100 n.). Odpowiedzialność analizowana jest dwukierunkowo:

- odpowiedzialność za: własny rozwój i własne postępowanie, drugiego człowieka, relacje interpersonalne, wspólnotę w której człowiek żyje i funkcjonuje, Ojczyznę;

- odpowiedzialność przed: sobą, drugim człowiekiem, instancją prawną, Bogiem.

Punktem wyjścia w pracy pedagogicznej nauczyciela jest więc zdobycie wiedzy o fenomenie odpowiedzialności, jako wartości warunkującej rozwój człowieczeństwa, przejawianie postawy odpowiedzialności za własny integralny rozwój, działania pedagogiczne oraz integralny rozwój ucznia. Drugim ważnym zadaniem jest edukacja aksjologiczna uczniów w zakresie tej wartości. Na uwagę 
w tym względzie zasługuje zdobycie przez uczniów wiedzy na temat istoty odpowiedzialności, jej kategorii, funkcji w życiu człowieka, reflektowanie poziomu swojej odpowiedzialności, gotowości do jej urzeczywistniania. Punktem zaś dojścia będzie urzeczywistnianie na wysokim poziomie odpowiedzialności. Bycie wzorem człowieka, ucznia odpowiedzialnego za siebie, za drugiego człowieka, z którym przyszło mu żyć, funkcjonować, pracować, uczyć się.

Miłość stanowi kolejny przymiot osoby, jako wielka wartość warunkująca piękno i pełnię człowieczeństwa. U jej podstaw jest relacja z drugą osobą, pragnienie jej dobra, spełnianie siebie.

Jak podkreśla Cz. Bartnik ,, miłość jest całoosobowym zwróceniem się osoby rozumnej, wolnej i twórczej ku drugiej osobie lub społeczności [...] dla ich dobra [...], a ostatecznie w celu spełnienia naszej osoby w innych, a innych w nas". (Bartnik 2003, s. 579). Jest wartością o holistycznym znaczeniu. Miłość ogarnia całego człowieka, ,ogarnia uczucia człowieka oraz wolę i uzdalnia ją do działania, a także inspiruje sferę intelektualną; jest doświadczeniem człowieka. $Z$ jednej strony spełnia człowieka, z drugiej rodzi poczucie szczęścia. W aspekcie psychologicznym miłość decyduje o ludzkiej dojrzałości osobowościowej w wymiarze indywidualnym i społecznym. W aspekcie teologicznym stanowi treść świętości zjednoczenia człowieka z Bogiem, jest kryterium zbawienia" (Maj 2009, s. 277).

Pierwszym priorytetowym zadaniem nauczyciela staje się zdobywanie wiedzy na temat tej wielkiej wartości, jej funkcji w życiu człowieka $\mathrm{w}$ aspekcie indywidualnym i społecznym; obdarowywanie miłością wychowawczą uczniów; wyposażenie ich w wiedzę o tej wartości, wspomaganie w zrozumieniu jej funkcji w życiu człowieka i wspólnot, budzenie wrażliwości na drugiego człowieka.

Zadaniem uczniów, na tym wstępnym etapie aksjologicznej drogi urzeczywistniania tej wartości, jest zdobycie wiedzy o jej fenomenie, reflektowanie miłości, którą uczeń obdarowuje swoich bliskich, rodziców, przyjaciół, osoby postronne, zwierzęta, to znaczy przejawia gotowość wyrażania miłości.

Punktem zaś dojścia po stronie nauczyciela i ucznia jest urzeczywistnianie tej wartości na takim poziomie, że można powiedzieć o każdym z nich: człowiek kochający.

Zdolność do twórczości to szczególny przymiot osoby ludzkiej wyróżniający ją od innych bytów, pozwalający budować kulturę, w niej się wyrażać i potwierdzać. Jest ona określana jako „działalność teoretyczna i praktyczna, której celem jest twórczy człowiek z jego zdolnościami i umiejętnościami, umożliwiającymi twórcze życie, aktywność wyrażająca się w sprawności przekształcania i wytwarzania czegoś nowego oraz oryginalnego, ściśle związana z poznaniem, inteligen- 
cją, motywacją, cechami osobowości oraz środowiskiem społeczno-kulturowym i wychowawczym, stanowi przedmiot filozofii, teorii sztuki, estetyki, historii sztuki, psychologii, pedagogiki, socjologii oraz prakseologii" (Najder-Stefaniak, 2016, s. 1183).

Działalność twórcza jest atrybutem człowieczeństwa, stąd prawo do twórczości przysługuje każdej osobie. W tym kontekście można mówić o obowiązku twórczości. Jak podkreśla A. Cudowska: „Twórczość jest jedną z podstawowych cech człowieka i przynależy każdemu podmiotowi, chociaż w różnym stopniu u poszczególnych jednostek, zależnie od czynników wewnętrznych (genetycznych) i zewnętrznych (środowiska przyrodniczego i społecznego) (Cudowska, 2004, s. 27). Twórcza aktywność nauczyciela wydaje się być właściwą odpowiedzią na problemy pedagogiczne związane z rozwojem ucznia oraz właściwym rozwojem zawodowym. Należy przy tym podkreślić, za K. Najder-Stefaniak, że „twórcze działanie, poznanie czy komunikowanie angażuje intelekt, intuicję iemocje" (Najder-Stefaniak, 2016, s. 1183). Stanowi drogę do pokonywania ograniczeń, pozwala przełamywać utarte schematy - działać transformatywnie, wartościować blokady i zablokowania, pozwala osiągać rezultat zasługujący na miano twórczego. Stanowi jeden $\mathrm{z}$ istotnych warunków rozwijania twórczości dziecka. Bowiem trudno by nauczyciel, nieposiadający kompetencji twórczych, rozwijał je w swoich uczniach. Rozpatrując aktywność twórczą nauczyciela w edukacji wczesnoszkolnej odnosimy ją do celu, jak również do warunku rozwoju edukacji. Cel i warunek znajdują dwa odniesienia: do nauczyciela i ucznia. Rozpatrując twórczość, jako warunek rozwoju edukacji, ogniskujemy takie elementy, jak: twórcza atmosfera, twórczy nauczyciel, twórcza szkoła i klasa szkolna. Wszystkie te elementy mają na celu kształtowanie twórczej postawy ucznia, ale też zwracając się do twórczego rozwoju nauczyciela w procesie wychowania integralnie związanego z nauczaniem. Twórcza postawa uczniów wyrażać się będzie w kreatywnym nastawieniu do rzeczywistości, otwartości na nowe doświadczenia, na rzeczy, zjawiska oraz procesy nowe i nieznane (Górniewicz, 1997, s. 87).

Punktem dojścia urzeczywistniania twórczości jest nauczyciel i uczeń. Człowiek twórczy, który podejmuje - na miarę swojej roli i rozwoju - działania przynoszące nowe wytwory, wprowadza w życie nowe i lepsze rozwiązania, reorganizuje zastaną rzeczywistość, stawia zadania, u podstaw których jest poszukiwanie, projektowanie, niwelowanie rozbieżności między stanem rzeczywistym a idealnym, cechuje go myślenie twórcze i wyobraźnia twórcza, niepokój twórczy, radość tworzenia (Wiechnik, 1996, s. 46-47).

Transcendencja to kolejny przymiot osoby ludzkiej. Nie będzie zbyt dużym błędem, jeśli określimy go mianem: przymiot finalny, co oznaczałoby wyrażający 
najpełniej istotę osoby $\mathrm{w}$ dynamicznym wymiarze. Zagadnienie transcendencji, mimo swej doniosłości, nie znajduje należnego miejsca w literaturze pedagogicznej. Transcendencja najogólniej oznacza przekraczanie progu, granicy. Jest ona właściwością dynamizmu osoby. Według K. Wojtyły najdobitniej wyraża się w czynie osoby oraz poprzez: wolność, samozastosowanie, samopanowanie, prawdę o dobru, rozstrzyganie i wybieranie, powinność, odpowiedzialność, wartości - ostatecznie w sumieniu, spełnianie siebie, szczęśliwość, duchowość (Wojtyła 2000, s. 60-268).

Według K. Wojtyły ,transcendencja osoby w czynie to nie tylko samozależność, zależność od własnego ,,ja”. Wchodzi w nią równocześnie moment zależności od prawdy i moment ten ostatecznie kształtuje wolność. Nie realizuje się ona bowiem przez podporządkowanie sobie prawdy, ale przez podporządkowanie się prawdzie. Zależność od prawdy określa granice właściwej osobie ludzkiej autonomii [...] Zależność od tej prawdy konstytuuje osobę w jej transcendencji; transcendencja wolności przechodzi w transcendencję moralności" (Wojtyła, 2000, s. 198-199). Ten sam autor wyróżnia transcendencję poziomą i pionową. Transcendencja pozioma wyraża się w przekraczaniu podmiotu ku przedmiotowi, czyli intencjonalność. Transcendencja pionowa wyraża się w czynie - działaniu moralnie wartościowym. „Jest to transcendencja, którą zawdzięczamy samostanowieniu, transcendencja przez sam fakt wolności, bycia wolnym w działaniu, a nie tylko przez intencjonalne chcenie w stronę właściwego im przedmiotu, wartości, celu" (Wojtyła, 2000, s. 164).

W transcendencję osoby jest „dwustronnie” wpisana natura. Osoba jest poddana naturze, ale przystosowuje naturę do swoich celów. Jak zaznacza M. Nowak: ,,poprzez projekt wypracowany przez osobę zachodzi transcendentowanie osoby ponad przeżywane „doświadczenie” i otwieranie na „przyszłe doświadczenia". Chodzi zwłaszcza o projekty ukierunkowane na rozwiązywanie powstających problemów, które stają przed osobą, umożliwiając jej stawianie hipotez możliwych rozwiązań i otwieranie się - na bazie już przeżytych „doświadczeń” - na nowe możliwe doświadczenia”. Szczególną właściwością człowieka jako osoby jest też i to, że jego projekty przekraczają horyzont tylko tego, co jest sprawdzalne i manifestuje się jako ,dążenie skierowane na transcendencję, określane często transcendencją osoby” (Nowak, 2013, s. 25). To skierowanie na transcendencję stanowi wskaźnik tożsamości osoby wyrażający się w docieraniu do jej misterium w perspektywie dobra rozwojowego (Nowak, 2013, s. 25). M. Nowak transcendencję ujmuje w sposób dynamiczny, otwierający na spotkanie z wartościami najwyższymi, podążanie ku Bogu. Jak podkreśla cytowany 
autor: „w takim ujęciu wszelkie ograniczenia i limity otwierają się na perspektywę wartości, które wychodzą poza ich ramy. Osoba nie tylko przekracza aktualny stan, ale również sama siebie. Urzeczywistniając swoje człowieczeństwo i sięgając do jego istoty, jeszcze pełniej staje się sobą we własnym człowieczeństwie, wyistacza się, pokonując ograniczenia aktualnego stanu" (Nowak, 2013, s. 16).

Mimo złożoności zagadnienia, jakim jest transcendencja, powinna ona znaleźć swe należne miejsce w edukacji wczesnoszkolnej. Punktem wyjścia jest zdobycie przez nauczyciela wiedzy o transcendencji - jej istocie, funkcji w życiu człowieka. Drugim ważnym zagadnieniem jest opracowanie sytuacji edukacyjnych: wychowawczo-dydaktycznych, na bazie których będzie następowała transcendencja ucznia. Doświadczenie transcendencji przez dziecko w tym wieku powinno stać się źródłem wiedzy o tym przymiocie osoby. Punktem dojścia powinno być doświadczenie transcendencji nauczyciela i doświadczenia ucznia, zamykające się w poczuciu wartości siebie, zadowoleniu, spełnieniu siebie, szczęśliwości.

Zachodzące procesy w edukacji wczesnoszkolnej, zmierzające do urzeczywistniania przymiotów osoby, przedstawia poniższy schemat.

Schemat 1. Urzeczywistnianie przymiotów osoby w procesie edukacji wczesnoszkolnej

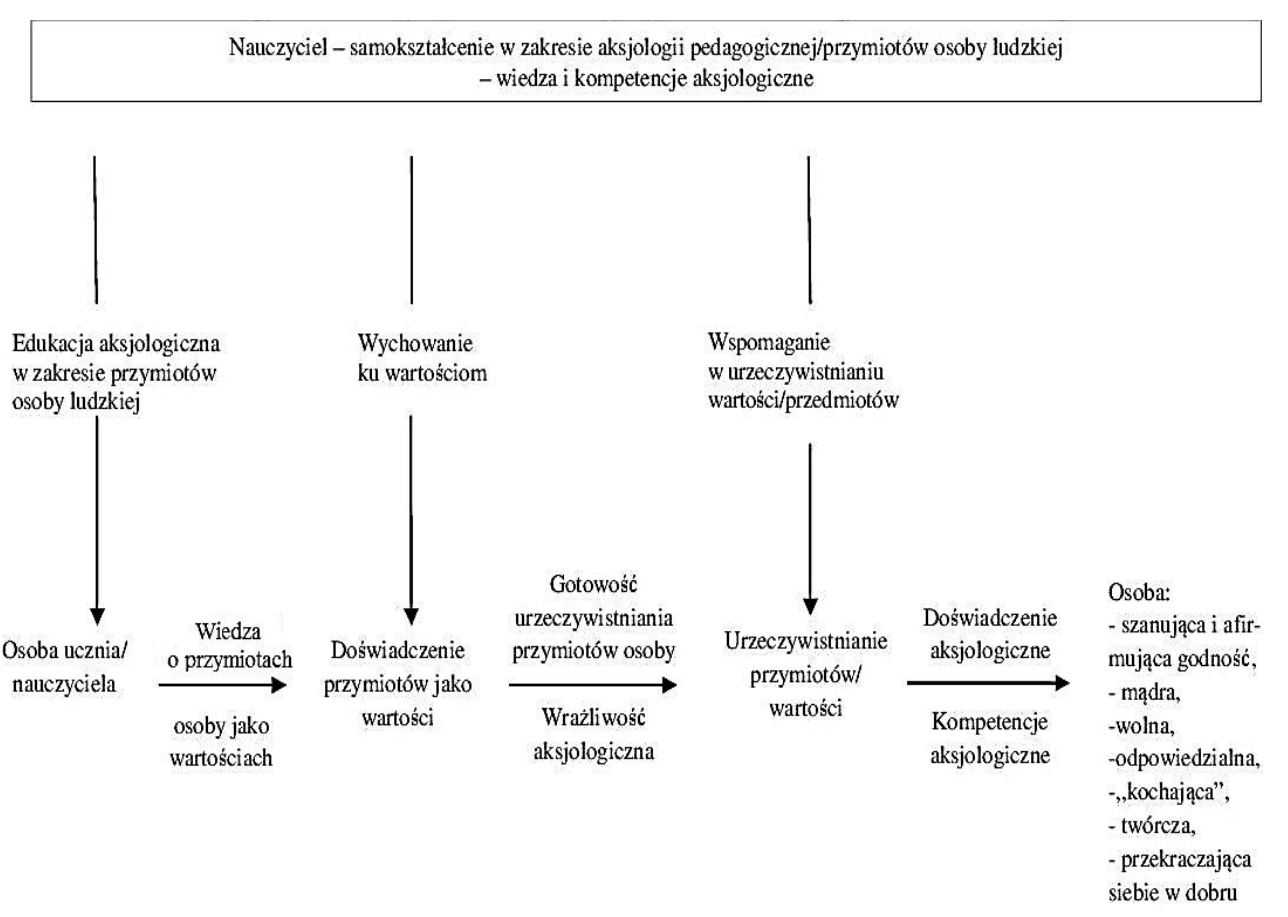


Powyżej wskazane na schemacie 1 procesy wymagają bardziej szczegółowych zadań odnoszących się do nauczyciela i ucznia. Ich zakres przedstawiony został w tabeli 1.

Tabela 1.

\begin{tabular}{|c|c|}
\hline Punktem wyjścia dla nauczyciela jest: & Punktem wyjścia dla ucznia jest: \\
\hline $\begin{array}{l}\text { - być wzorem osobowym godnym naślado- } \\
\text { wania w świetle przymiotów osoby; } \\
\text { - postawić w centrum pracy pedagogicznej przy- } \\
\text { mioty osoby ludzkiej i uczynić z nich cele wy- } \\
\text { chowawczo-dydaktyczne; } \\
\text { - podjąć edukację aksjologiczną (własną oraz } \\
\text { ucznia) w zakresie przymiotów osoby; }\end{array}$ & $\begin{array}{l}\text { - zdobyć wiedzę aksjologiczną w zakresie } \\
\text { przymiotów osoby; } \\
\text { - zrozumieć ich funkcję w życiu człowieka } \\
\text { na miarę swojego rozwoju; } \\
\text { - zaakceptować przymioty osoby jako wartości; } \\
\text { - budzić w sobie wrażliwość na przymioty } \\
\text { osoby jako wartości; }\end{array}$ \\
\hline $\begin{array}{l}\text { - permanentnie dawać świadectwo urzeczy- } \\
\text { wistniania przymiotów; } \\
\text { - stwarzać warunki do urzeczywistniania przy- } \\
\text { miotów osoby; } \\
\text { - stwarzać warunki do samooceny urzeczywist- } \\
\text { niania wartości/ przymiotów; } \\
\text { - zbudować autorską koncepcję pedagogiczną } \\
\text { edukacji aksjologicznej i wychowania, której ce- } \\
\text { lem jest urzeczywistnianie przymiotów osoby }\end{array}$ & $\begin{array}{l}\text { - zaangażować się w urzeczywistnianie przy- } \\
\text { miotów osoby; } \\
\text { - dokonywać oceniające go reflektowanie } \\
\text { urzeczywistniania przymiotów; }\end{array}$ \\
\hline Punktem dojścia dla nauczyciela jest: & Punktem dojścia dla ucznia jest: \\
\hline $\begin{array}{l}\text { - być wzorem osobowym godnym naślado- } \\
\text { wania; } \\
\text { - permanentnie wspomagać uczniów w stawaniu } \\
\text { się wzorem osobowym godnym naśladowania. }\end{array}$ & $\begin{array}{l}\text { - zaangażować się w urzeczywistnianie przy- } \\
\text { miotów osoby; } \\
\text { - dokonywać oceniające go reflektowanie } \\
\text { urzeczywistniania przymiotów. }\end{array}$ \\
\hline
\end{tabular}

\section{PODSUMOWANIE}

Osoba posiada przymioty: godność, rozumność-mądrość, wolność, odpowiedzialność, zdolność do miłości, zdolność do twórczości i transcendencji. Powinny one stanowić podstawę aksjologiczną procesu edukacji wczesnoszkolnej, w której centrum znajduje się osoba ucznia i nauczyciela. Urzeczywistnianie tych przymiotów poprzez edukację aksjologiczną, doświadczanie wartości, ich urzeczywistnianie, nabywanie kompetencji aksjologicznych sprawia, że te dwa główne podmioty edukacji stają się wzorami osobowymi godnymi naśladowania. 


\section{BIBLIOGRAFIA}

BARTNIK, Cz. (2003). Dogmatyka katolicka. T. 2. Lublin: Wydawnictwo KUL.

CudowsKA, A. (2004). Ksztattowanie twórczych orientacji życiowych $w$ procesie edukacji. Białystok: Wydawnictwo Trans Humana.

ChlEwiŃSKI, Z., ZALESKI, Z. (1989). Godność. W: Encyklopedia Katolicka. Lublin: Towarzystwo Naukowe KUL

ChŁodna-BŁach, I. (2016). Odpowiedzialność. W: K. ChaŁas, A. Maj (red.), Encyklopedia Aksjologii Pedagogicznej (s. 670-672). Radom: Wydawnictwo POLWEN.

GóRniEwICZ, J. (1997). Kategorie pedagogiczne. Odpowiedzialność, podmiotowość, samoreagulacja, tolerancja, twórczość, wyobraźnia. Olsztyn: Wydawnictwo UWM.

MAJ, A. (2009). Wartości religijne w aspekcie teologicznym. W: K. CHAŁAS, A. MAJ, J. MARIAŃSKI (red.), Wychowanie ku wartościom religijnym (s. 235-307). Lublin-Kielce: Wydawnictwo Jedność.

MatulKa, Z. (1997). Wychowanie do wolności jako podstawowy problem pedagogiczny. W: M. NowaK, T. KunoŁowicz (red.), Pedagogika ogólna. Podstawowe problemy aksjologiczne (s. 243-250). Lublin: Wydawnictwo KUL.

Najder-StefaniaK, K. (2016). Twórczość. W: K. ChaŁas, A. Maj (red.), Encyklopedia Aksjologii Pedagogicznej (s. 1183-1188). Radom: Wydawnictwo POLWEN.

NowaK, M. (2016). Mądrość. W: K. ChaŁas, A. MaJ (red.), Encyklopedia Aksjologii Pedagogicznej (s. 572-575). Radom: Wydawnictwo POLWEN.

NowAK, M. (2013). Pedagogika personalistyczna - wyzwania i nadzieja dnia dzisiejszego. W: K. Guzowski, A. Kostecka, G. BARTH (red.), Osoba a wychowanie (s. 13-31). Lublin: Wydawnictwo KUL.

Nowosad, S., Wyrostkiewicz, M. (2014). Wolność. W: Wielka Encyklopedia Nauczania Jana Pawta II (s. 586-588). Radom: Wydawnictwo POLWEN.

SKOROWSKI, H. (2014). Demokracja przestrzenią poszanowania człowieka. W: S. FEL, M. WódKA (red.), Godność osoby ludzkiej w spoteczeństwie i gospodarce (s. 329-339). Lublin: Wydawnictwo KUL.

STEUdEN, S. (2011). Mądrość jako pozytywny aspekt starzenia się. W: S. STEUden, M. STANOwsKa, J. JANOWSKI (red.), Starzenie się z godnościa (s. 71-82). Lublin: Wydawnictwo KUL.

WIECHNIK, R. (1996). Intelektualne i kreatywne aspekty zdolności do uczenia się. Lublin: Wydawnictwo UMCS.

Wierzbicki, A. (2016). Osoba. W: K. ChaŁAS, A. MAJ (red.), Encyklopedia Aksjologii Pedagogicznej (s. 694-697). Radom: Wydawnictwo PoLwEN.

WoJTYŁA K. (2000). Osoba i czyn oraz inne studia antropologiczne. Red. T. STYCZEŃ, W. Chudy, J.W. GaŁKowsKi, A. Rodziński, A. Szostek. Lublin: Towarzystwo Naukowe KUL.

WoJTYŁA K. (2003). Rozważania o istocie człowieka. Kraków: Wydawnictwo WAM.

Stownik wspótczesnego języka polskiego (1998). Warszawa: Wydawnictwo Przegląd Reader's Digest.

\section{OSOBA PUNKTEM WYJŚCIA I DOJŚCIA W EDUKACJI WCZESNOSZKOLNEJ}

$$
\text { Streszczenie }
$$

W edukacji na każdym jej poziomie biorą udział dwa jej główne podmioty: uczeń i nauczyciel. Przyjmując personalistyczne ich ujęcie, w którym człowiek jest rozumiany jako osoba, jednocześnie przyjmujemy uniwersalistyczny, refleksyjny i mądrościowy sposób ujęcia wychowania, którego centrum stanowi osoba ze swym indywidualnym, biologicznym, psychologicznym, społecznym, duchowym i religijnym wymiarem. 
Istota edukacji wczesnoszkolnej sprowadza się więc do rozwoju osoby ludzkiej, jej dojrzałości osobowościowej. Wzajemne relacje nauczyciel-uczeń ukierunkowane są na urzeczywistnianie przymiotów osoby, by pełniej przeżywać swoje człowieczeństwo.

Słowa kluczowe: osoba; przymioty osoby; edukacja wczesnoszkolna.

\section{THE PERSON AS A STARTING AND ENDING POINT IN EARLY SCHOOL EDUCATION}

\section{S u m m a ry}

Two of its main subjects participate in education at its every level and teacher. Accepting a personalistic approach to them, in which a person is understood as a person, we simultaneously accept a universalist, reflective and wise way of approaching education, the center of which is a person with his individual, biological, psychological, social, spiritual and religious dimensions.

The essence of early school education boils down to the development of the human person, his personality maturity. Mutual teacher-student relations are focused on the actualization of the person's qualities to fulfill his humanity more fully.

Key words: person; person attributes; early school education. 